\title{
The gas vesicles, buoyancy and vertical distribution of cyanobacteria in the Baltic Sea
}

\section{Anthony E. Walsby , Paul K. Hayes \& Rolf Boje}

To cite this article: Anthony E. Walsby , Paul K. Hayes \& Rolf Boje (1995) The gas vesicles, buoyancy and vertical distribution of cyanobacteria in the Baltic Sea, European Journal of Phycology, 30:2, 87-94, DOI: 10.1080/09670269500650851

To link to this article: http://dx.doi.org/10.1080/09670269500650851

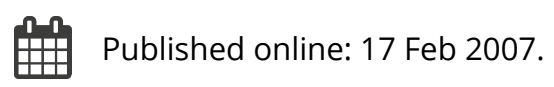

Submit your article to this journal $\sqsubset$

Џll Article views: 606

Q View related articles $\sqsubset$

Citing articles: 29 View citing articles 5 


\title{
The gas vesicles, buoyancy and vertical distribution of cyanobacteria in the Baltic Sea
}

\author{
ANTHONY E. WALSBY ${ }^{1}$, PAUL K. HAYES ${ }^{1}$ AND ROLF BOJE ${ }^{2}$ \\ ${ }^{1}$ School of Biological Sciences, University of Bristol, Woodland Road, Bristol BS8 IUG, UK \\ ${ }^{2}$ Institut für Meereskunde an der Universität Kiel, Düsternbrooker Weg 20, D-24105 Kiel 1, Germany \\ (Received 25 February 1994; accepted 1 November 1994)
}

\begin{abstract}
The mean pressures required to collapse gas vesicles in turgid cells of cyanobacteria from the Baltic Sea were 0.91 MPa (9.1 bar) in Aphanizomenon flos-aquae, 0.83 MPa in Nodularia sp. collected from the main deep basins and 0.34 MPa in Nodularia from shallower coastal regions. The gas vesicles were strong enough to withstand the depth of winter mixing, down to the permanent halocline $(60 \mathrm{~m}$ in the Bornholm Sea, $90 \mathrm{~m}$ in the Eastern Gotland Sea) or to the sea bottom ( $30 \mathrm{~m}$ or less in the shallow Arkona Sea and Mecklenburg Bight). The cyanobacteria had low cell turgor pressures, within the range 0.08-0.18 MPa. The colonies were highly buoyant: the Aphanizomenon colonies floated up at a mean velocity of $22 \mathrm{~m}$ per day and the Nodularia colonies at $36 \mathrm{~m}$ per day. The colonies remained floating when up to half of the gas vesicles had been collapsed. In summer the cyanobacteria were mostly restricted to the water above the thermocline and in calm conditions their concentration increased towards the top of the water column. A series of colony concentration profiles indicated that, following a deep mixing event, the population of colonies moved upward with a net velocity of $22 \mathrm{~m}$ per day, similar to the colony floating velocity. This demonstrated that the buoyancy provided by gas vesicles would give a selective advantage to populations of cyanobacteria by enabling them to float into the higher irradiance of the near-surface water.
\end{abstract}

Key words: Baltic Sea, buoyancy, cyanobacteria, gas vacuoles, waterblooms.

\section{Introduction}

In the Baltic Sea there are several types of filamentous cyanobacteria, notably species of Anabaena, Aphanizomenon and Nodularia, which produce populations that float near the water surface and form surface waterblooms under calm conditions (Geitler, 1932; Niemi, 1979; Hübel \& Hübel, 1980; Śmarda et al., 1986; Komàrek et al., 1993). These populations may be so extensive that they can be seen in satellite photographs (Horstmann, 1983). Similar surface waterblooms are formed by planktonic cyanobacteria in freshwater lakes (Reynolds \& Walsby, 1975; Reynolds, 1987) and by several species of Trichodesmium in tropical oceans (Carpenter et al., 1992), where it has been shown that the cyanobacteria float up because they are rendered buoyant by gas vacuoles (Walsby, 1978). Gas vacuoles are known to be present in some of the cyanobacteria of the Baltic Sea (Gumpert et al., 1987; Hübel \& Hübel, 1980; Śmarda et al., 1986; Komàrek et al., 1993), but there has been no previous investigation of their role in providing buoyancy and influencing the vertical distribution of the cyanobacteria in these waters.

The gas vacuoles of cyanobacteria are formed from hollow cylindrical structures called gas vesicles (Bowen \& Jensen, 1965). Gas vesicles are rigid and withstand application of moderate pressures with little shrinkage in volume (Walsby, 1982), but they collapse irreversibly when subjected to a certain critical pressure (Walsby,
1971). Inside cells they are subjected to cell turgor pressure, which varies from less than $0.1 \mathrm{MPa}$ ( 1 bar) in halophilic cyanobacteria (Walsby et al., 1983b) to as much as $0.55 \mathrm{MPa}$ in freshwater cyanobacteria (Kinsman et al., 1991). No direct measurements of turgor pressure have previously been made in cyanobacteria from marine or brackish waters.

In natural waters gas vesicles are also subjected to hydrostatic pressure, which increases with depth by approximately $0.01 \mathrm{MPa} \mathrm{m}^{-1}$. Cyanobacteria from deep lakes tend to have stronger gas vesicles than those in shallow ones (Utkilen et al., 1985; Walsby, 1994). The range of mean critical pressure for gas vesicles varies from less than $0.3 \mathrm{MPa}$ for cyanobacteria from shallow brine pools (Walsby et al., 1983b) to over 3.5 MPa in species of Trichodesmium in the deep oceans (Walsby, 1978); those in cyanobacteria from freshwater lakes usually range between 0.5 and 1.0 MPa (Hayes \& Walsby, 1986; Walsby \& Bleything, 1988). The waters of the Baltic range in depth from less than $10 \mathrm{~m}$ along the coastal shallows to more than $200 \mathrm{~m}$ in a number of "deeps", though circulation of cyanobacteria to depths greater than $60-90 \mathrm{~m}$ will normally be restricted by gradients of temperature and salinity (Kullenberg, 1981).

We investigated the gas vesicles, buoyancy and vertical distribution of planktonic cyanobacteria in parts of the Baltic Sea during the summers of 1992, 1993 and 1994. We related the critical pressure distribution of the gas 
vesicles to depth and we obtained evidence for the role of gas vesicles in maintaining these organisms within the euphotic zone. Other factors that have been implicated in the success of cyanobacteria in these waters include their ability to fix nitrogen (Hübel \& Hübel, 1980), the possibility that their growth is promoted by high phosphorus availability and a low N:P ratio (Niemi, 1979), and the possibility that they are subjected to less grazing than other groups (Hernroth \& Ackefors, 1979). Factors leading to the formation of cyanobacterial waterblooms are discussed in detail by Reynolds \& Walsby (1975), Reynolds (1987), and in the compendium edited by Vincent (1987).

\section{Materials and methods}

\section{Sampling}

This investigation was made in the Baltic Sea on the F.S Poseidon from 2 to 14 August 1992, on the F.S. Alkor from 26 July to 6 August 1993, and on the F.S. Littorina from 31 July to 13 August 1994. Drift-stations were marked by a drogue, near the Eastem Gotland Sea (depth 210-240 m) and north-east of Bornholm Island (depth 90-100 m).

Cyanobacteria were collected from the sea with either $20 \mu \mathrm{m}$ or $100 \mu \mathrm{m}$ mesh plankton nets, drawn vertically from a depth of $10 \mathrm{~m}$ to the surface. Floating colonies of Aphanizomenon and Nodularia were drawn off from the surface of net samples left to stand for an hour. Drops of the suspension were placed on a polycarbonate Petri dish under a binocular microscope; the colonies, which floated to the centre of the convex drops, were withdrawn with a syringe and then cleaned by transfer through further drops of filtered seawater.

The vertical distribution of colonies in the seas was determined in samples collected at depth intervals of $5 \mathrm{~m}$ using General Oceanics 12-litre sampling bottles on a rosette array. Samples, usually of 21 , were filtered through $2 \mathrm{~cm}$ diameter nylon filters of $20 \mu \mathrm{m}$ mesh. These were mounted in filtered seawater under coverslips and the numbers of colonies or filaments of cyanobacteria were counted using a dissecting microscope.

\section{Measurements on gas vesicles and buoyancy}

The critical pressure distributions of gas vesicles in the cyanobacteria were determined using a portable pressure nephelometer (Walsby, 1973). Colonies were dispersed with a glass Potter homogeniser. The mean critical pressure $\left(p_{\mathrm{c}}\right.$ or $p_{\mathrm{a}}$ ) and median critical pressures (at which $50 \%$ of the gas vesicles collapsed) were calculated by the methods of Walsby \& Bleything (1988). Figures are given as means \pm standard deviations. Cell turgor pressure was determined as $p_{t}=p_{\mathrm{c}}-p_{\mathrm{a}}$, where $p_{\mathrm{c}}$ is the value obtained with cells suspended in seawater containing 0.5-1.5 M sucrose, and $p_{\mathrm{a}}$ is the value with cells suspended in seawater (Walsby, 1973).

The proportion of colonies floating in a water sample was determined by leaving $3 \mathrm{ml}$ samples to stand in Utermöhl sedimentation chambers for $15 \mathrm{~min}$ and then counting those colonies floating under the coverslip and those sinking onto the base (Walsby \& Booker, 1980).

To determine the proportion of colonies floating after collapsing different proportions of the gas vesicles, suspensions were placed in $1.5 \mathrm{ml}$ Eppendorf tubes, inverted in the seawater-filled nephelometer tubes, and subjected to pressures of $0 \cdot 4-1.3 \mathrm{MPa}$ in steps of $0.1 \mathrm{MPa}$. The inverted tubes prevented colonies from floating near the gas-water interphase; without this precaution some gas vesicles become infiltrated with gas and survive the gas pressure rise (see Walsby, 1971, 1994). The pressuretreated samples were diluted and transferred to the Utermöhl chambers for analysis of the proportion of colonies floating.

The floating velocities of colonies were determined from the time taken to float up between gradation marks on a $50 \mathrm{ml}$ measuring cylinder. The colony was expelled near the bottom of the water column from a $2 \mathrm{~mm}$ diameter cannula attached to a $5 \mathrm{ml}$ syringe. The cylinder was secured in a gimbaled beaker containing a layer of cooled water to generate a temperature gradient that would prevent convectional mixing.

\section{Measurements of physiocochemical gradients}

The vertical profile of photon irradiance in the water was measured with a $4 \pi$ LiCor sensor. Other measurements of depth, temperature and salinity were made by instruments attached to the CTD rosette sampler.

\section{Results}

\section{Description of cyanobacteria}

Four morphological types of cyanobacteria could be distinguished at each of the Baltic sampling sites; the nomenclature of Komàrek et al. (1993) is followed for the Nodularia spp.

1. Aphanizomen flos-aquae (L.) Ralfs: cells cylindrical, $4.5 \mu \mathrm{m}$ wide and $7-15 \mu \mathrm{m}$ long; filaments arranged in parallel arrays, showing gliding movements over one another that cause colonies to change shape, from flat bundles (flakes) to elongate spears; either dark green or straw-coloured (Figs 1, 2).

2. Nodularia litorea Kützing: separate straight filaments; discoid cells $15-17 \mu \mathrm{m}$ wide [i.e. at the upper size range given by Komàrek et al. (1993)] and 2-8 $\mu \mathrm{m}$ long (Fig. 4).

3. Nodularia spumigena Mertens: coiled filaments either singly or in tangled colonies; cells $11-12 \mu \mathrm{m}$ wide and 3-6 $\mu \mathrm{m}$ long (Figs 5, 6).

4. Nodularia sp.: tightly coiled filaments; cells $6.5-8 \mu \mathrm{m}$ wide and $2-5 \mu \mathrm{m}$ long (Fig. 3). This organism resembled N. spumigena (Komàrek et al., 1993, fig. $7 \mathrm{Af}$ ). It occurred in low numbers, usually less than $1 \%$ of the total. 

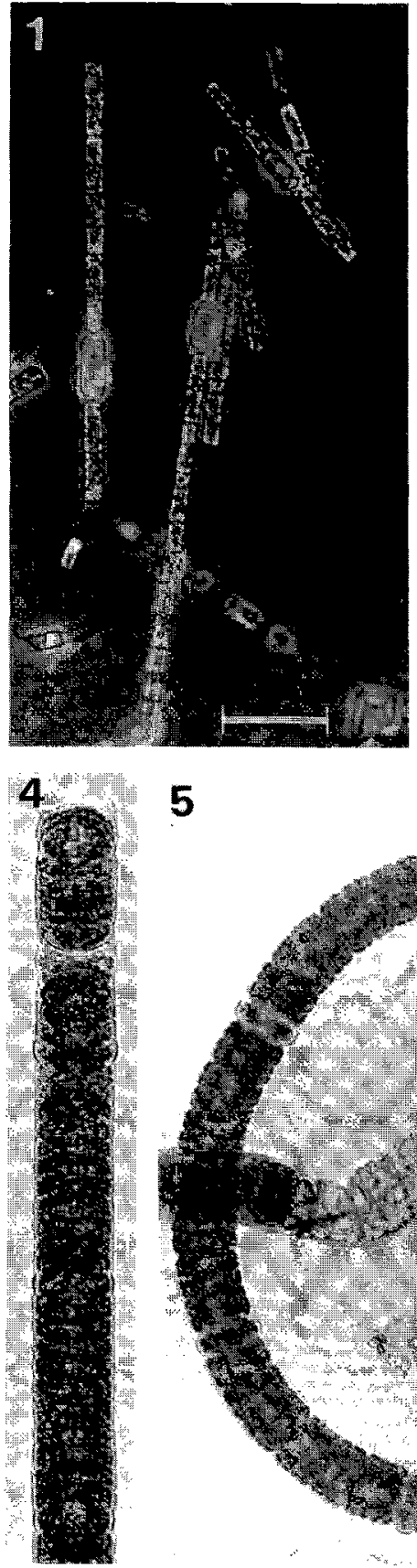



2

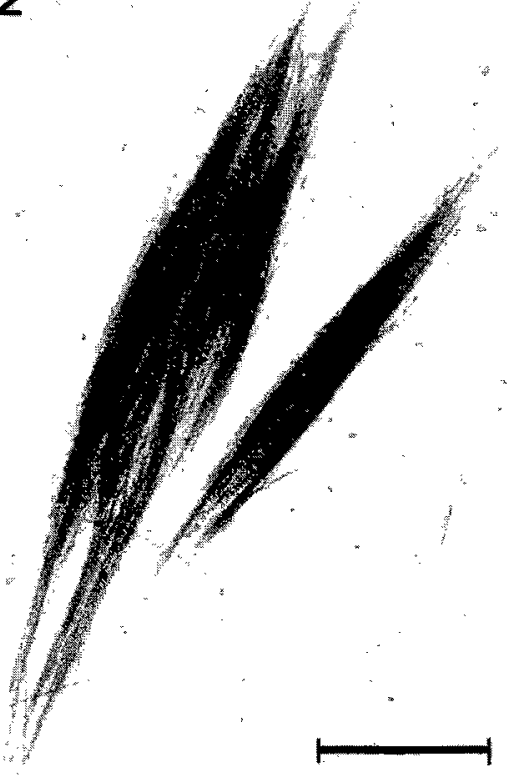

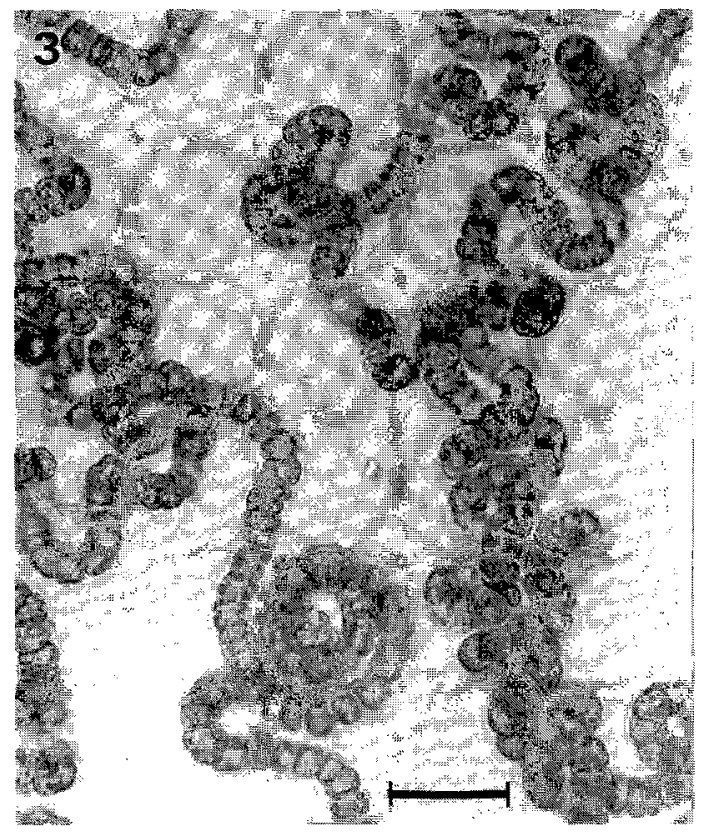

6

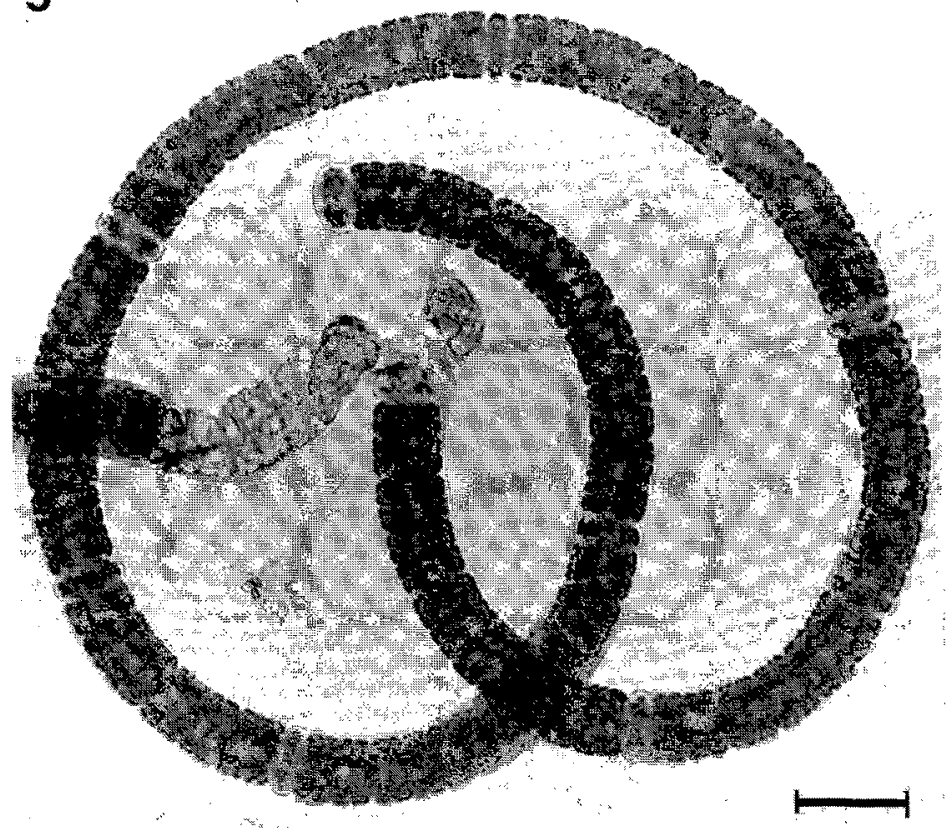

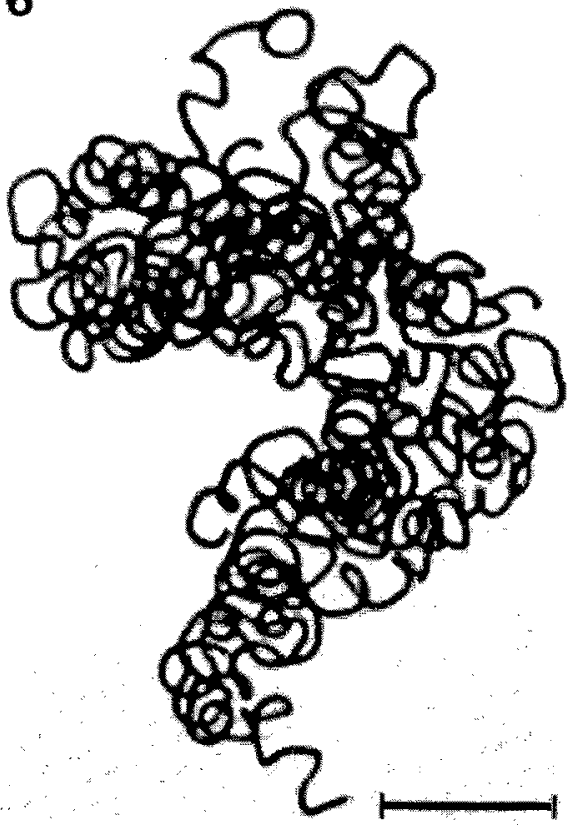

Figs 1-6. Light micrographs of cyanobacteria from the Baltic Sea. Fig. 1. Filaments of Aphanizomenon flos-aquae showing two heterocysts and cells with peripheral gas vacuoles (appearing light in phase contrast). Fig. 2. Two fusiform colonies of Aphanizomenon flos-aquae. Fig. 3. Tightly coiled form of Nodularia sp. Fig. 4. Filament of the straight form of Nodularia litorea showing spaced heterocysts. Fig. 5. Filament of the coiled form of Nodularia spumigena. Fig. 6. Colony of the coiled form of Nodularia spumigena. Scale bars represent $200 \mu \mathrm{m}$ in Figs 2 and 6, and $20 \mu \mathrm{m}$ in Figs 1, 3 and 5 (Fig. 4 is the same magnification as Fig. 5).

\section{Critical pressure of the gas vesicles}

The critical pressure distributions of mixed populations of Aphanizomen and Nodularia collected during August 1992, July 1993 and August 1994 from different sites showed wide variation (Table 1 ). The lowest mean apparent critical pressure $\left(p_{a}\right)$ recorded was $0.34 \pm 0.18 \mathrm{MPa}$ for flocs of cyanobacteria floating in a loose surface scum in the Mecklenburg Bight (Fig. 7, curve a). The material had a pale-whitish coloration and contained some apparently senescent filaments.
Samples collected off the islands of Gotland and Bornholm had stronger gas vesicles, usually with a mean $p_{\mathrm{a}}$ of 0.79-0.97 MPa; excluding samples showing bimodal distributions (see below), the mean $p_{\mathrm{a}}$ was $0.86 \pm 0.05 \mathrm{MPa}(n=37)$. The example shown in Fig. 7 (curve c) is for a sample, consisting mainly of Aphanizomenon with some Nodularia, that was used to investigate the relationship between buoyancy and gas vesicle content (see below, and Fig. 9); $p_{\mathrm{a}}$ was $0.90 \pm 0.30 \mathrm{MPa}$.

Some of the critical pressure curves obtained with colonies of Nodularia were bimodal, suggesting two 
Table 1. Mean critical pressures of gas vesicles in colonies of Nodularia sp. and Aphanizomenon sp. collected from the Baltic Sea in August 1992, July 1993 and August 1994

\begin{tabular}{|c|c|c|c|c|c|c|c|}
\hline Research vessel & Date & Latitude $\mathrm{N}$ & Longitude $\mathrm{E}$ & Mean $p_{\mathrm{a}}$ or $\left[p_{\mathrm{c}}\right] / \mathrm{MPa}$ & Median $p_{\mathrm{a}}$ or $\left[p_{\mathrm{c}}\right] / \mathrm{MPa}$ & Replicate samples & Cyanobacterium \\
\hline \multirow[t]{22}{*}{ F.S. Poseidon } & 3 Aug 92 & $54^{\circ} 34^{\prime}$ & $11^{\circ} 14^{\prime}$ & $0 \cdot 415$ & $0 \cdot 411$ & 2 & $\mathrm{~m}$ \\
\hline & 3 Aug 92 & $54^{\circ} 25^{\prime}$ & $11^{\circ} 48^{\prime}$ & $0 \cdot 344$ & 0.333 & 3 & $(A p h)$ \\
\hline & 5 Aug 92 & $57^{\circ} 18^{\prime}$ & $19^{\circ} 46^{\prime}$ & 0.922 & 0.975 & 3 & Aph \\
\hline & 6 Aug 92 & $57^{\circ} 20^{\prime}$ & $19^{\circ} 50^{\prime}$ & 0.793 & 0.825 & 1 & $(A p h)$ \\
\hline & 6 Aug 92 & $57^{\circ} 20^{\prime}$ & $19^{\circ} 50^{\prime}$ & 0.606 & 0.467 & 1 & Nod \\
\hline & 6 Aug 92 & $57^{\circ} 20^{\prime}$ & $19^{\circ} 50^{\prime}$ & 0.793 & 0.900 & 1 & Aph \\
\hline & 6 Aug 92 & $57^{\circ} 20^{\prime}$ & $19^{\circ} 50^{\prime}$ & {$[0.903]$} & {$[0.955]$} & 1 & Aph \\
\hline & 6 Aug 92 & $57^{\circ} 20^{\prime}$ & $19^{\circ} 50^{\prime}$ & 0.784 & 0.881 & 2 & $\mathrm{~m}$ \\
\hline & 6 Aug 92 & $57^{\circ} 20^{\prime}$ & $19^{\circ} 50^{\prime}$ & {$[0.853]$} & {$[0.934]$} & 2 & $\mathrm{~m}$ \\
\hline & 7 Aug 92 & $57^{\circ} 21^{\prime}$ & $19^{\circ} 56^{\prime}$ & 0.868 & 0.960 & 1 & $\mathrm{~m}$ \\
\hline & 7 Aug 92 & $57^{\circ} 21^{\prime}$ & $19^{\circ} 56^{\prime}$ & {$[0 \cdot 907]$} & {$[0.968]$} & 1 & $\mathrm{~m}$ \\
\hline & 7 Aug 92 & $57^{\circ} 21^{\prime}$ & $19^{\circ} 56^{\prime}$ & 0.839 & 0.918 & 1 & $\mathrm{~m}$ \\
\hline & 8 Aug 92 & $57^{\circ} 22^{\prime}$ & $19^{\circ} 57^{\prime}$ & 0.706 & 0.784 & 3 & $\mathrm{~m}$ \\
\hline & 8 Aug 92 & $57^{\circ} 22^{\prime}$ & $19^{\circ} 57^{\prime}$ & 0.801 & 0.870 & 3 & $\mathrm{~m}$ \\
\hline & 8 Aug 92 & $57^{\circ} 22^{\prime}$ & $19^{\circ} 57^{\prime}$ & $0 \cdot 888$ & 0.933 & 3 & $\mathrm{~m}$ \\
\hline & 9 Aug 92 & $55^{\circ} 53^{\prime}$ & $17^{\circ} 23^{\prime}$ & 0.912 & 0.979 & 2 & Aph \\
\hline & 9 Aug 92 & $55^{\circ} 15^{\prime}$ & $15^{\circ} 59^{\prime}$ & 0.891 & 0.928 & 1 & $\mathrm{~m}$ \\
\hline & 9 Aug 92 & $55^{\circ} 15^{\prime}$ & $15^{\circ} 59^{\prime}$ & 0.883 & 0.938 & 2 & $(A p h)$ \\
\hline & 9 Aug 92 & $55^{\circ} 15^{\prime}$ & $15^{\circ} 59^{\prime}$ & {$[0.903]$} & {$[0.931]$} & 2 & $(A p h)$ \\
\hline & 10 Aug 92 & $55^{\circ} 13^{\prime}$ & $15^{\circ} 56^{\prime}$ & 0.842 & 0.873 & 2 & $\mathrm{~m}$ \\
\hline & 10 Aug 92 & $55^{\circ} 13^{\prime}$ & $15^{\circ} 56^{\prime}$ & 0.932 & 0.978 & 3 & $\mathrm{~m}$ \\
\hline & 11 Aug 92 & $55^{\circ} 11^{\prime}$ & $15^{\circ} 51^{\prime}$ & 0.907 & 0.946 & 2 & $\mathrm{~m}$ \\
\hline \multirow[t]{8}{*}{ F.S. Alkor } & $26 \mathrm{Jul} 93$ & $54^{\circ} 26^{\prime}$ & $12^{\circ} 14^{\prime}$ & 0.810 & 0.895 & 1 & $\mathrm{~m}$ \\
\hline & 26 Jul 93 & $54^{\circ} 42^{\prime}$ & $12^{\circ} 38^{\prime}$ & 0.831 & 0.917 & $I$ & $\mathrm{~m}$ \\
\hline & $27 \mathrm{Jul} 93$ & $54^{\circ} 48^{\prime}$ & $13^{\circ} 18^{\prime}$ & 0.859 & 0.923 & 1 & $\mathrm{~m}$ \\
\hline & $27 \mathrm{Ju}\rfloor 93$ & $54^{\circ} 48^{\prime}$ & $13^{\circ} 18^{\prime}$ & 0.831 & 0.884 & $I$ & Nod \\
\hline & 29 Jul 93 & $55^{\circ} 09^{\prime}$ & $15^{\circ} 41^{\prime}$ & 0.807 & 0.871 & 3 & $\mathrm{~m}$ \\
\hline & 30 Jul 93 & $55^{\circ} 09^{\prime}$ & $15^{\circ} 44^{\prime}$ & 0.969 & 1.005 & 2 & $A p h$ \\
\hline & $30 \mathrm{Jul} 93$ & $55^{\circ} 09^{\prime}$ & $15^{\circ} 44$ & {$[0.807]$} & {$[0.859]$} & 2 & $A p h$ \\
\hline & 31 Jul 93 & $55^{\circ} 12^{\prime}$ & $15^{\circ} 45^{\prime}$ & 0.853 & 0.931 & 3 & $\mathrm{~m}$ \\
\hline F.S. Littorina & 6 Aug 94 & $59^{\circ} 15^{\prime}$ & $19^{\circ} 54^{\prime}$ & 0.869 & 0.930 & 3 & $(A p h)$ \\
\hline
\end{tabular}

Numbers in italics indicate bimodal distributions (excluded from statistical analysis).

Square brackets indicate $p_{\mathrm{c}}$ of cells suspended in 0.5-1.5 M sucrose.

Nod, selected Nodularia filaments; Aph, selected Aphanizomenon colonies; (Aph), mostly Aphanizomenon; m, mixed Nodularia and Aphanizomenon.

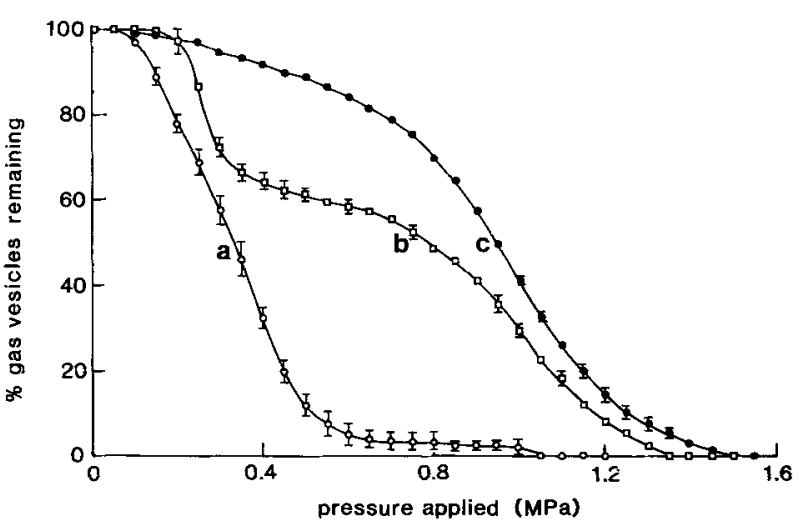

Fig. 7. Critical pressure distributions of gas vesicles in cyanobacteria: (a) in flocs of colonies from a surface waterbloom in the Mecklenburg Bight (open circles); (b) in a suspension of mixed Nodularia colonies (open squares); $(c)$ in mixed cyanobacteria from a net tow in the Baltic Sea northeast of Bomholm (filled circles). Points shown are the means and standard deviations of three measurements. populations of gas vesicles with mean $p_{\mathrm{a}}$ values of about $0.3 \mathrm{MPa}$ and 1.0 MPa (Fig. 7, curve b). In one such sample removal of the bleached tangles of filaments resulted in a reduction in the proportion of the weaker gas vesicles. In August 1994, a year in which the surface water temperature was above $20^{\circ} \mathrm{C}$, much of the Nodularia was in a bleached condition and the critical pressure distributions were strongly bimodal.

To determine whether the differences in critical pressure were associated with particular genera or species rather than regional populations, further measurements were made on samples of single colony types picked out by syringe. Suspensions of about 100 homogenised Aphanizomenon colonies gave curves almost identical with Fig. 7 (curve c), with a $p_{\mathrm{a}}$ of $0.91 \pm 0.32 \mathrm{MPa}$. The critical pressure distributions were similar in Aphanizomenon colonies picked from samples taken east of Gotland Island in $1992\left(p_{\mathrm{a}}=0.91 \mathrm{MPa}\right)$ and east of Bornholm in $1993\left(p_{\mathrm{a}}=0.97 \mathrm{MPa}\right)$ and there was no evidence of populations of this cyanobacterium with much weaker gas vesicles.

Samples of Nodularia spumigena colonies indicated two types of gas vesicles. In August 1992, colonies in the 




Fig. 8. Critical pressure distributions of gas vesicles in cyanobacteria suspended in seawater (open circles) and seawater containing $1.5 \mathrm{M}$ sucrose (filled circles) to remove turgor pressure.

shallower water of the Arkona Sea has gas vesicles with a low mean critical pressure $\left(p_{\mathrm{a}}=0.34 \mathrm{MPa}\right)$ like that shown in Fig. 7 (curve a); those east of Bornholm in 1993 had stronger gas vesicles $\left(p_{\mathrm{a}}=0.83 \mathrm{MPa}\right)$. Bimodal curves (e.g. Fig. 7, curve b) were also obtained with Nodularia colonies from water samples in the Gotland sea.

Critical pressure determinations were also made on cultures of Nodularia spp., strains 279, 282, 297, 306, 307 and 311, from the Biological Station, Hiddensee, Culture Collection (E. M. Arndt University of Greifswald), established by Dr M. Hübel from seawater samples collected near the islands of Hiddensee and Rügen (Komàrek $e$ t al., 1993). All these organisms possessed rather weak gas vesicles; for the six strains the mean value of $p_{\mathrm{a}}$ was $0 \cdot 34 \pm 0 \cdot 04 \mathrm{MPa}$.

\section{Turgor pressure}

In a mixed sample of cyanobacteria from east of Bornholm, the mean critical pressures increased with the addition of sucrose from $0.85 \mathrm{MPa}$ to $0.98 \mathrm{MPa}$. The highest value, found in $1.5 \mathrm{M}$ sucrose (Fig. 8), indicated an average turgor pressure of $0.13 \mathrm{MPa}$ in these samples. Previous analyses on filaments from Aphanizomenon colonies suspended in lower concentrations of sucrose $(0.5 \mathrm{M})$ indicated turgor pressures of $0.08 \mathrm{MPa}$. In the six cultured strains of Nodularia spp., $p_{\mathrm{c}^{\prime}}$ determined with the filaments suspended in $0.5 \mathrm{M}$ sucrose, was $0.52 \pm 0.04$ $\mathrm{MPa}$. The difference between $p_{\mathrm{c}}$ and $p_{\mathrm{a}}$ indicated a turgor pressure $p_{\mathrm{t}}=0.18 \pm 0.05 \mathrm{MPa}$, a little higher than in the material from the sea.

\section{Buoyancy state of cyanobacteria}

The majority of the colonies and filaments collected in the net tows from the top $10 \mathrm{~m}$ of the water column in the drift-station northeast of Bornholm were positively buoyant. In the sedimentation chambers $93 \%$ of the Aphanizomenon colonies $(n=260)$ and $95 \%$ of the straight Nodularia filaments $(n=57)$ floated. Only $67 \%$ of the coiled Nodularia filaments $(n=86)$ floated, but many of those that sank were entangled with long-spined cells of Chaetoceros sp., and other sedimenting organisms.

\section{Buoyancy in relation to gas vesicle content}

Application of a pressure of $1.6 \mathrm{MPa}$ caused all floating cyanobacteria to sink, confirming that their buoyancy was solely due to their gas vesicle content. The pressures required to cause $50 \%$ of the cyanobacteria to sink were 0.91 MPa for Aphanizomenon, 0.94 MPa for the coiled Nodularia, and $0.88 \mathrm{MPa}$ for the straight Nodularia filaments (Fig. 9).

The proportion of gas vesicles collapsed in a series of pressure steps in a mixed population of cyanobacteria (Fig. 7, curve c) was compared with the proportion of the filaments floating after each increment (Fig. 9b). It does
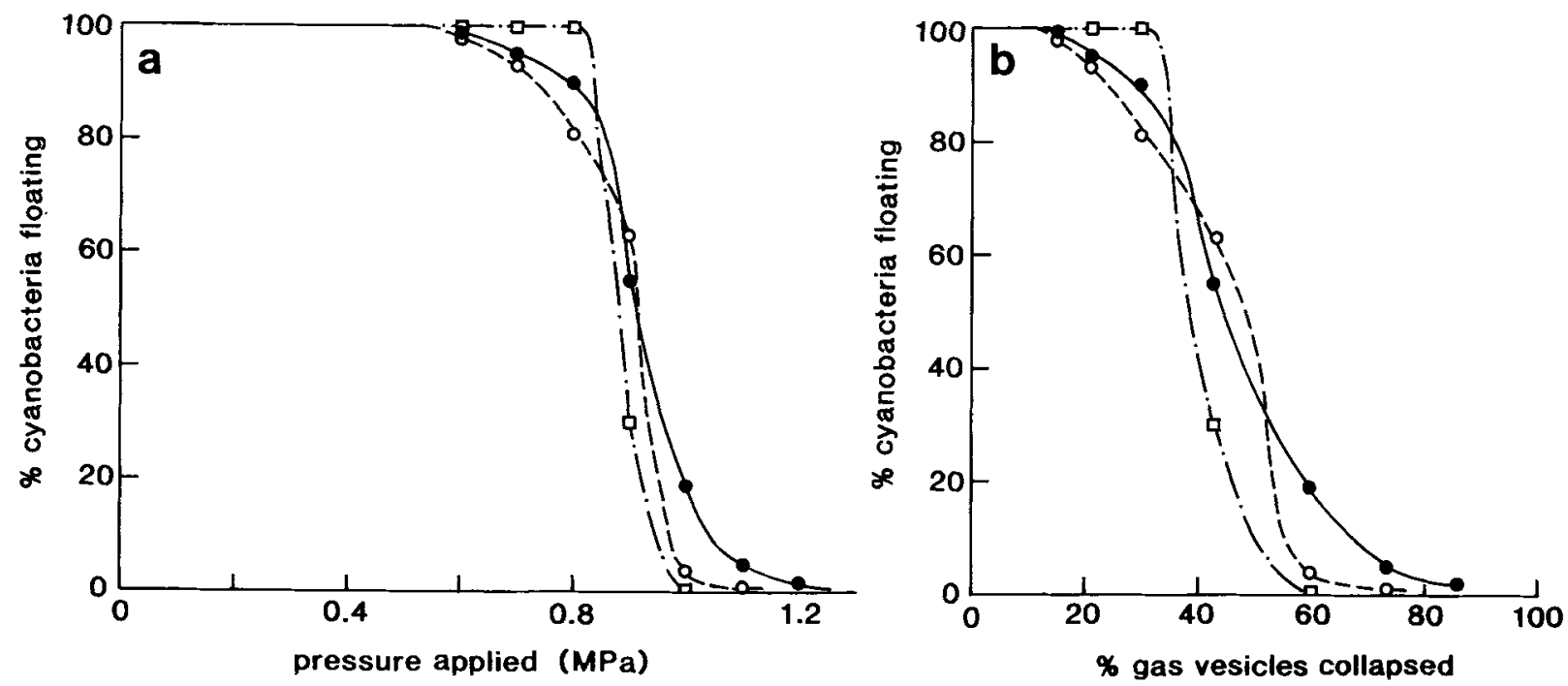

Fig. 9. (a) The buoyancy state of cyanobacteria after application of different pressures: filled circles, Aphanizomenon flos-aquae; open squares, straight Nodularia litorea filaments; open circles, coiled Nodularia spumigena filaments. (b) The same data on buoyancy state related to the proportion of gas vesicles collapsed in the mixed population of cyanobacteria, calculated from curve (c) in Fig. 7. 
not necessarily follow that the proportion of gas vesicles lost was the same in each of the cyanobacteria, though comparison of the three curves in Fig. $9 a$ supports the conclusion that the critical pressure distributions of gas vesicles in the three cyanobacteria were broadly similar.

\section{Floating velocities of the cyanobacteria}

For seven colonies of Aphanizomenon from surface-bucket samples taken from a calm sea containing a patchy surface waterbloom, the mean floating velocity $\left(U_{\mathrm{f}}\right)$ was $27 \pm 4 \mathrm{~m}$ per day. For 14 colonies from $0-10 \mathrm{~m}$ net tows in the Gotland sea $U_{\mathrm{f}}$ was $20 \pm 15 \mathrm{~m}$ per day. For a further 25 colonies from $0-10 \mathrm{~m}$ net tows from the sea near Bornholm, $U_{\mathrm{f}}$ was $2 \mathrm{I} \pm 13 \mathrm{~m}$ per day. Hence the overall mean for the 46 Aphanizomenon colonies was $22 \pm 13 \mathrm{~m}$ per day. Similar measurements made for 20 colonies of the coiled Nodularia gave a $U_{\mathrm{f}}$ of $36 \pm 16 \mathrm{~m}$ per day.

These measurements, on colonies of various sizes, were made to determine whether the flotation velocities were high enough to affect the distribution of colonies under calm conditions (see below). No attempt was made to relate flotation velocity to the range of colony size present.

Vertical distribution of the cyanobacteria in the water column

Vertical profiles revealed a steep thermocline at $20-25 \mathrm{~m}$ between the surface at $17-19^{\circ} \mathrm{C}$ and the deeper water at $6-7^{\circ} \mathrm{C}$, at all the sampling stations during the 1992 cruise. Within the surface layer shallow temperature gradients developed during times of relative calm. At the drift-station the salinity of the water above the thermocline remained constant at $8.7 \%$; the density of the water and stability of the water column were therefore determined solely by variations in temperature. The similarities of surface water salinity (Fig. $10 a-c$ ) indicate that the same water mass was followed at the drift station.

The concentrations of the cyanobacterial colonies were negligible at depths below $30 \mathrm{~m}$, e.g. four Aphanizomenon colonies in $40 \mathrm{l}$ of water from a depth of $50 \mathrm{~m}(0 . \mathrm{I}$ colonies $\mathrm{I}^{-1}$ compared with between 2 and $721^{-1}$ above the thermocline). In seven depth profiles, the highest concentrations were always within the top $10 \mathrm{~m}$ of the water column.

A series of profiles made at the Bornholm drift-station showed that the vertical distribution of colonies was influenced by their flotation and by vertical mixing. At 1800 hours on 9 August a difference of only $0.3^{\circ} \mathrm{C}$ between the surface and $15 \mathrm{~m}$ indicated there had been mixing to this depth. The next $24 \mathrm{~h}$ were calm (Beaufort $1-3)$; the depth of the surface mixed layer decreased to $7 \mathrm{~m}$ at 0800 hours next morning (Fig. 10a) and to $1 \mathrm{~m}$ by 1330 hours (Fig. 10b), indicating a stable water column. The profile of colony concentration indicated that the population had floated upwards, with the highest
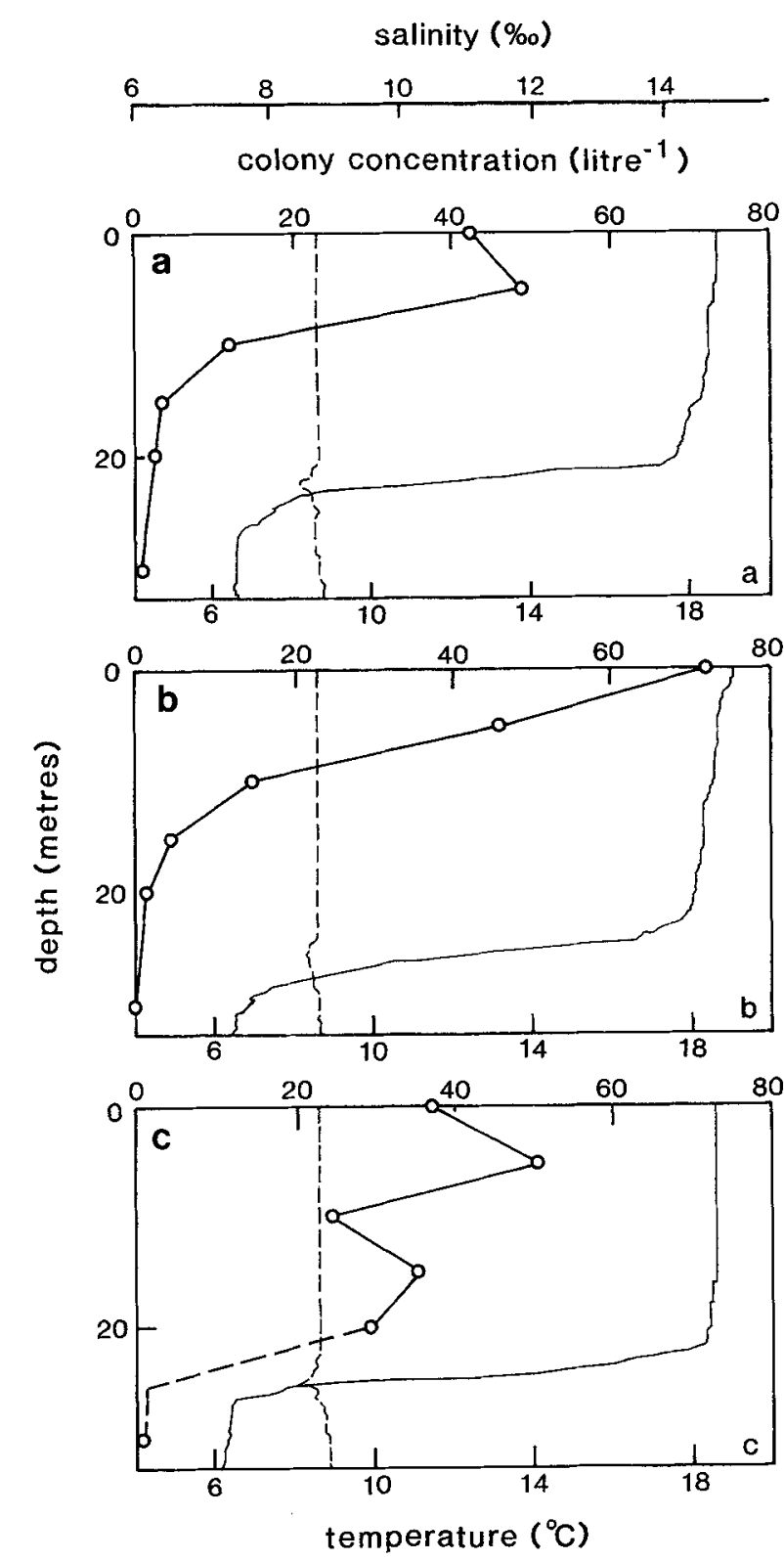

Fig. 10. Vertical profiles of Aphanizomenon colony concentration (open circles), temperature (continuous lines) and salinity (broken lines) in the Baltic Sea north-east of Bornholm Island $\left(55^{\circ} 13^{\prime} \mathrm{N}\right.$, $15^{\circ} 56^{\prime} \mathrm{E}$ ) at (a) 0800 hours (b) 1330 hours on 10 August, and (c) 1000 hours on 11 August 1992.

concentration, 72 colonies $\mathrm{I}^{-1}$, near the surface (Fig. $10 b)$. The wind speed rose from Beaufort 1 at 2000 hours to 7 at 2300 hours and remained at between 4 and 6 until the following day. At 1000 hours on 11 August the water temperature was uniform down to $20 \mathrm{~m}$ and the profile showed that the colony population had been mixed down to this depth (Fig. 10c).

Comparison of the colony concentration profiles in Fig. $10 a$ and $10 b$ indicates that some of the population had moved up by about $5 \mathrm{~m}$ in the $5.5 \mathrm{~h}$ between the time of these two samples. This suggests a net upward velocity of $22 \mathrm{~m}$ per day, which is the same as the mean floating velocity of the Aphanizomenon colonies (see above). The upward movement of the population can therefore be accounted for by flotation. 


\section{Discussion}

Critical pressure of the gas vesicles in relation to depth of the Baltic Sea

A survey of planktonic cyanobacteria in various habitats suggests that the gas vesicles present are usually no stronger than is required to withstand the maximum pressures they experience (Walsby, 1994). This trend seems to hold for gas vesicles in the Baltic cyanobacteria.

Cyanobacteria in water samples from the shallow water of the Arkona Sea and Mecklenburg Bight had gas vesicles with a median $p_{\mathrm{a}}$ of $0.37 \mathrm{MPa}$, and a similar value, $p_{\mathrm{a}}=0.34$, was found for cultures of Nodularia taken by $M$. Hübel from coastal waters around Hiddensee and Rügen. A majority of the cyanobacteria retained their buoyancy with $50 \%$ of gas vesicles collapsed (Fig. 9). This indicates that these organisms from coastal waters would remain buoyant after mixing to depths of $30 \mathrm{~m}$.

Gas vesicles in Aphanizomenon, Anabaena and Nodularia from the major basin of the Baltic Sea, however, showed a much greater median $p_{\mathrm{a}}$ of 0.78-1.01 MPa. Over half the gas vesicles in the cyanobacteria investigated withstood a pressure exceeding $0.9 \mathrm{MPa}$ (Table 1 ), which is the hydrostatic pressure developed by a water column of $90 \mathrm{~m}$ depth. This greatly exceeds the depth above which $99 \%$ of the summer population of cyanobacteria are found, i.e. the depth of the thermocline at about $25 \mathrm{~m}$.

Although the population of planktonic cyanobacteria reaches its maximum during the summer months when the water is thermally stratified, it must develop from an inoculum that survives over winter, either suspended in the water column or on the shallower parts of the sea bottom. The upper $60-90 \mathrm{~m}$ or so of the Baltic basin turns over in the winter. Below the halocline at $60-90 \mathrm{~m}$ is a layer of more saline water (Kullenberg, 1981) which does not usually mix with the overlying layers. For much of the period from winter to early spring the planktonic cyanobacteria will circulate down to the depths of the halocline, but not deeper. It would appear, therefore, that the considerable strength of the gas vesicles in these organisms is an adaptation for maintaining buoyancy through the winter period of circulation. A similar argument has been used to explain the occurrence of strong gas vesicles in species of Oscillatoria from deep Norwegian lakes (Walsby et al., 1983a).

Some species of both Aphanizomenon and Nodularia produce akinetes (Rippka et al., 1979). During their differentiation the akinetes of gas-vacuolate species lose their gas vesicles and sink to the bottom sediments, where they may overwinter (but see Livingstone \& Jaworski, 1980; Rother \& Fay, 1977). The filaments that germinate from the akinetes must form new gas vesicles in order to regain buoyancy; they can do this only if sufficient gas vesicles withstand the pressures generated by the overlying water column.

\section{Effect of buoyancy on vertical distribution}

The buoyancy provided by gas vesicles in the cyanobacteria of the Baltic Sea enables colonies of these organisms to float upwards at velocities of about $20 \mathrm{~m}$ per day relative to the water mass. Even in light winds this velocity is likely to be exceeded by the vertical shear velocity $\left(u_{*}\right)$ in the surface mixed layer of the water column. The shear velocity can be calculated from the equation

$$
u_{*}^{2}=\left(\rho_{\mathrm{a}} / \rho\right) \mathcal{C}_{\mathrm{d}} u_{\mathrm{w}}^{2}
$$

where $\rho_{\mathrm{a}}$ is the density of $\operatorname{air}\left(\mathrm{T} \cdot 2 \mathrm{~kg} \mathrm{~m}^{-3}\right), \rho$ is the density of the Baltic seawater ( $\left.1005 \mathrm{~kg} \mathrm{~m}^{-3}\right), C_{\mathrm{d}}$ is the neutral drag coefficient $\left(1.3 \times 10^{-3}\right)$ and $U_{w}$ is the wind speed (Spigel \& Imberger, 1987). It can be calculated that $u_{*}$ exceeds the mean floating velocity of the cyanobacterial colonies $\left(0.23 \times 10^{-3} \mathrm{~m} \mathrm{~s}^{-1}\right)$ when the wind speed exceeds $0.21 \mathrm{~m} \mathrm{~s}^{-1}$, and that $u_{*}$ exceeds the velocity of the fastest floating colonies $\left(0.7 \mathrm{~m} \mathrm{~s}^{-1}\right)$ at wind speeds greater than $0.63 \mathrm{~m} \mathrm{~s}^{-1}$ (cf. $0.3-1.5 \mathrm{~m} \mathrm{~s}^{-1}$ at Beaufort 1 ). This explains why surface waterblooms do not form unless the water column is stabilised by thermal density gradients that reach very close to the water surface.

In very windy conditions the water column became mixed down to the region of the seasonal thermocline and the colonies were dispersed throughout the water above the thermocline (Fig. 10). Buoyancy would still have been of value in preventing colonies from sinking through the thermocline. It would therefore have guaranteed a longer residence time within surface waters. During this investigation the depth of the mixed layer $\left(z_{\mathrm{m}}=20-23 \mathrm{~m}\right)$ did not greatly exceed the depth of the euphotic zone $\left(z_{\text {eu }}=15 \mathrm{~m}\right)$ and colonies circulating within the mixed layer would therefore have exhibited net primary production (Reynolds, 1984).

During calm conditions (Beaufort $1-2$ ) the decrease in the depth of the surface mixed layer would have enabled the cyanobacteria to float up and become concentrated further up the vertical light gradient (Humphries \& Lyne, 1988). This would have provided an advantage not obtained by phytoplankton that remained in suspension by having low sedimentation velocities (Ibelings et al., 1991). The faster the cyanobacteria float up the closer they will approach the water surface and the more time they will spend in the euphotic zone (Reynolds \& Walsby, 1975). Since the speed of flotation increases with the square of radius (Stokes's equation) there will be selection for cyanobacteria with large filaments (the straight Nodularia litorea filaments) or those that aggregate in colonies (formed by the coiled Nodularia filaments and by Aphanizomenon). Large size and colonial habit hold disadvantages for nutrient uptake and light absorption (Raven, 1986; Fogg, 1991); these must therefore be outweighed by advantages provided by buoyancy discussed here.

We suggest that the buoyancy provided by gas vesicles is advantageous to the planktonic cyanobacteria of the Baltic in two respects. The first is that it enables 
those which have survived the winter to float up into the surface waters when the seasonal thermocline is established in the spring; it is now necessary to obtain information on the vertical distribution of these organisms throughout the annual cycle. The second is that it enables the cyanobacteria to move up the vertical light gradient during periods of calm throughout the summer season. A quantitative assessment of the advantage this provides can be made by calculating the extra amount of light the cyanobacteria would intercept by successive migrations to the water surface.

\section{Acknowledgements}

We thank Gary Barker, Ursula Junghans, Ute Kumitz and Annegret Stuhr for skilled technical assistance, Alexander Welter for operating the CTD sampler, and the crews of the F.S. Poseidon, F.S. Alkor and the F.S. Littorina. We are grateful to Edward Carpenter for comments on the manuscript, and to Helmut and Marianne Hübel for kindly providing cultures of Nodularia. This work was supported by the Institut für Meereskunde an der Universität Kiel, and by grants from the Natural Environment Research Council and the European Commission Environment Programme.

\section{References}

BOWEN, C.C. \& JENSEN, T.E. (1965). Blue-green algae: fine structure of the gas vacuoles. Science, 147: 146́0-1462.

Carpenter, E.J., CAPONE, D.G. \& Rueter, J.G. (1992). Marine Pelagic Cyanobacteria: Trichodesmium and other Diazotrophs. NATO ASI series C, vol. 362. Kluwer, Boston.

FoGG, G.E. (1991). The phytoplanktonic ways of life. New Phytol, 118: 191232.

GerTLER, L. (1932) Cyanophyceae. Akademische Verlagsgesellschaft, Leipzig.

GUMPERT, J., ŠmARDA, I., HÜBEL, M. \& HöBeL, H. (1987). Ultrastructural studies on the cyanobacterium Nodularia spumigena and its epiphytic bacteria of the genus Seliberia. J. Basic Microbiol, 27: 543-555.

HAYES, P.K. \& WALSBY, A.E. (1986). The inverse correlation between width and strength of gas vesicles in cyanobacteria. Br. phycol. J., 21, 191-197.

HeNROTH, L. \& ACKERFORS, H. (1979). The zooplankton of the Baltic proper. Inst. Mar. Res. Rep., 2: 60pp. Fishery Board of Sweden.

HORSTMANN, U. (1983). Distribution patterns of temperature and water colour in the Baltic Sea as recorded in satellite images: indicators for phytoplankton growth. Ber. Inst. Meeresk. Kiel, 106: 147-158.

HÜBEL, H. \& HǓBEL, M. (1980). Nitrogen fixation during blooms of Nodularia in coastal waters and backwaters of the Arkona Sea (Baltic Sea) in 1974 Int. Rev./ ges. Hydrobiol., 65: 793-808.

HUMPIRTES, S.E. \& LYNE, V.D. (1988). Cyanophyte blooms: the role of cell buoyancy. Limnol. Oceanogr., 33: 79-91.

IBELINGS, B.W., MUR, L.R., KINSMAN, R. \& WALSBY, A.E. (1991). Microcystis changes its buoyancy in response to the average irradiance in the surface mixed layer. Arch. Hydrobiol., 120: 385-401.
KINSMAN, R., IBELINGS, B.W. \& WALSBY, A.E. (1991). Gas vesicle collapse by turgor pressure and its role in buoyancy regulation by Anabaena flosaquae. J. Gen. Microbiol., 137: 1171-1178.

KomÀrex, J., Hübel, M., HüBel, H. \& ŠMARDA, J. (1993). The Nodularia studies. II. Taxonomy. Arch. Hydrobiol./Algolog. Studies, 68: 1-25.

KullenberG, G. (1981). Physical oceanography. In The Baltic Sea (Voipio, A., editor), 135-181. Elsevier, Amsterdam.

LIVINGSTONE, D. \& JAWORSKI, G.H.M. (1980). The viability of akinetes of bluegreen algae recovered from the sediments of Rostherne Mere. Br. phycol. J., 15: 357-364.

NiEMI, A. (1979). Blue-green algal blooms and N:P ratio in the Baltic Sea. Acta Bot. Fenn., 110: 57-61.

RAVEN, J.A. (1986). Physiological consequences of extremely small size for autotrophic organisms in the sea. In Photosynthetic Picoplankton (Platt, T. \& Li, W.K.W., editors), 1-70. Can. Bull. Fish. Aquat. Sci. 214.

REyNolds, C.S. (1984). The Ecology of Freshwater Phytoplankton. Cambridge University Press, Cambridge.

RernotDs, C.S. (1987). Cyanobacterial water-blooms. Adv. Bot. Res., 13:67143.

RENOLDS, C.S. \& WALSBY, A.E. (1975). Water-blooms. Biol. Rev., 50: 437481.

Rippka, R., Deruelles, J., Waterbury, J.B., Herdman, M. \& Stanier, R.Y. (1979). Generic assignments, strain histories and properties of pure cultures of cyanobacteria. J. Gen. Microbiol., 111, 1-61.

ROTHER, J.A. \& FAY, P. (1977). Sporulation and the development of planktonic blue-green algae in two Salopian meres. Proc. R. Soc. Lond., 50B: $317-332$

SMARDA, J., KOMÀRF, J. \& HÜBEL, H. (1986). SEM-analysis of colonies of the cyanophyte Nodularia water bloom from Baltic Sea. Arch. Hydrobiol. Suppl. 73/Algolog. Studies 44: 319-330.

SPIGEL, R.H. \& IMBERGER, J. (1987). Mixing processes relevant to phytoplankton dynamics in lakes. N.Z. J. Mar. Freshwater Res., 21: 361-377.

UTKILEN, H.C., SKULBERG, O.M. \& WALSBY, A.E. (1985). Buoyancy regulation and chromatic adaptation in planktonic Oscillatoria species: alternative strategies for optimising light absorption in stratified lakes. Arch. Hydrobiol., 104: 407-417.

VINCENT, W.F. (1987). Dominance of bloom-forming cyanobacteria (bluegreen algae). N.Z. J. Mar. Freshwater Res., 21: 361-542.

WAISBY, A.E. (1971). The pressure relationships of gas vacuoles. Proc. $R$. Soc. Lond., 178B: 301-326.

WALSBY, A.E. (1973). A portable apparatus for measuring relative gas vacuolation, the strength of gas vacuoles, and turgor pressure in planktonic blue-green algae and bacteria. Limnol. Oceanogr., 18: 653658.

WALSBY, A.E. (1978). The properties and buoyancy-providing role of gas vacuoles in Trichodesmium Ehrenberg. Br. phycol. J., 13: 103-116.

WALSBY, A.E. (1982). The elastic compressibility of gas vesicles. Proc. R. Soc. Lond., 216B: 355-368.

WALSBY, A.E. (1994). Gas vesicles. Microbiol. Rev, 58: 94-144.

WALSBY, A.E. \& BLEYTHING, A. (1988). The dimensions of cyanobacterial gas vesicles in relation to their efficiency in providing buoyancy and withstanding pressure. J. Gen. Microbiol., 134: 2635-2645.

WALSBX, A.E. \& BOOKER, M.J. (1980). Changes in buoyancy of a planktonic blue-green alga in response to light intensity. Br. phycol. J., 15: 311319.

WALSBY, A.E., UTKIIEN, H.C. \& JOHNSEN, I.J. (1983a). Buoyancy changes of a red coloured Oscillatoria agardhii in Lake Gjersjøen, Norway. Arch. Hydrobiol., 97: 18-38.

WALSBY, A.E., VAN Rin, J. \& COHEN, Y. (1983b). The biology of a new gasvacuolate cyanobacterium, Dactylococcopsis salina sp. nov., in Solar Lake. Proc. R. Soc. Lond., 217B: 417-447. 